\title{
OPTIMALISASI PERAN BADAN USAHA MILIK DESA (BUMDES) SINGAJAYA DALAM MENINGKATKAN KESEJAHTERAAN MASYARAKAT (STUDI KASUS DI DESA BODAS KECAMATAN WATUKUMPUL)
}

\author{
Iit Novita Riyantidan Hendri Hermawan Adinugraha
}

iitnovita21@gmail.com, hendri.hermawan@iainpekalongan.ac.id Institut Agama Islam Negeri Pekalongan

\begin{abstract}
ABSTRAK
Village development is one of the goals for equitable distribution of national development which has long been scheduled by the government, this is because villages still dominate poverty in Indonesia. One of the efforts made by the government for the welfare of rural communities is by establishing village-owned enterprises throughout Indonesia. The establishment of the Singajaya BUMDes was in accordance with Pemalang district regulation No. 9 of 2007 concerning Guidelines for the Establishment of Village-Owned Enterprises. The establishment of the Singajaya BUMDes aims to participate in village development and provide services to the community in its management carried out by the village government and the community. The existence of the Singajaya village-owned enterprises(BUMDes) is expected to be able to improve the village economy to create community welfare. The purpose of this study was to determine whether the role of the Singajaya BUMDes was optimal for the welfare of the village community or not. This research is a qualitative research with a descriptive approach. The results showed that the Singajaya BUMDes has played a role in improving the welfare of the community, but it has not been optimal in its implementation, the factors that become obstacles in running a business are limited human resources, weak managerial capacity and low capital. So the government's role is needed to conduct socialization and provide training and assistance to the community regarding the management of the Singajaya BUMDes so that it can be carried out properly and professionally.
\end{abstract}

\section{PENDAHULUAN}

Pembangunan desa dan daerah-daerah tertinggal sudah sejak lama menjadi agenda pemerintah sebagai tujuan pembangunan nasional karena desa merupakan sasaran riil yang harus disejahterakan dan juga pedesaan masih mendominasi kemiskinan yang terjadi di Indonesia. Dengan adanya pembangunan desa diharapkan dapat membangun kemandirian desa agar tidak bergantung dengan pusat. Untuk mendorong pembangunan tersebut salah satu cara yang dapat dilakukan yaitu dengan mendirikan Badan Usaha Milik Desa (BUMDes) sesuai pernyataan Peraturan Menteri Dalam Negeri No 39 tahun 2010 tentang badan usaha milik desa, yaituuntuk meningkatkan kemampuan keuangan pemerintah desa dalam penyelenggaraan pemerintahan dan meningkatkan pendapatan 
masyarakat melalui berbagai kegiatan usaha ekonomi masyarakat pedesaan, didirikan badan usaha milik desa sesuai dengan kebutuhan dan potensi desa.

BUMDes merupakan salah satu usaha desa dalam bentuk lembaga yang pengelolaanya dijalankan oleh pemerintah desa dan masyarakat desa guna mendorong peningkatan perekonomian masyarakat desa atau termasuk usaha dari desa, oleh desa dan untuk desa, namun dalam pelaksanaanya tetap mengacu pada kebutuhan masyarakat dan potensi desa yang ada. Sebagai lembaga ekonomi di pedesaan, BUMDes harus berbeda dengan lembaga ekonomi lainnya supaya dengan keberadaan serta kinerja BUMDes dapat berkontribusi dalam mewujudkan kesejahteraan bagi masyarakat desa. Selain itu juga untuk mencegah adanya usaha yang memiliki sistem kapitalis di pedesaan yang dapat mengganggu tatanan kehidupan di masyarakat.

Eksistensi BUMDes terus mengalami peningkatan dari tahun-tahun sebelumnya diketahui hingga tahun 2020 awal sudah sebanyak 46 ribu atau lebih dari $61 \%$ desa di Indonesia sudah memiliki Badan Usaha Milik Desa (BUMDes). Namun jika melihat dilapangan masih banyak yang belum berkembang atau hanya jalan ditempat dikarenakan badan hukum BUMDes yang belum jelas, dan juga sumber daya manusia yang masih rendah dalam pengelolaannya (BUMDes, 2020). Contoh yang terjadi di kecamatan Watukumpul berdasarkan penuturan ketua BUMDes Bodas jumlah BUMDes yang masih beroperasi sekitar dua desa, desa Bodas merupakan salah satunya, kebanyakan BUMDes yang berhenti beroperasi menjalankan usaha simpan pinjam faktor pembubarannya karena setoran pinjaman yang macet sehingga menjadikan kas BUMDes kosong dan modal dari dana desa yang diberikan tidak mampu mencukupi kebutuhan usahanya serta partisipasi masyarakat yang masih sangat rendah. Hal ini harus menjadi perhatian pemerintah desa untuk megetahui potensi desa sehingga tidak salah dalam memilih jenis usaha yang akan dilakukan dan pelaksanaannya memperoleh hasil yang dapat dirasakan secara luas dengan begitu tercapai kesejahteraan masyarakat secara berkelanjutan.

Melalui Undang-undang Nomor 32 Tahun 2004 tentang Pemerintah Daerah, pemerintah telah mendukung desa untuk mempunyai badan usaha, karena usaha milik desa ini secara proporsional dapat dijadikan wadah bagi pemerintah daerah dan masyarakat dalam melakukan progam pemberdayaan ekonomi pada tingkat desa. Keberadaan BUMDes diharapakan mampu menstimulasi dan menggerakan ekonomi masyarakat desa. Aset ekonomi yang dimiliki desa secara penuh harus di kelola oleh 
masyarakat desa. Pengelolaan BUMDes harus dilakukan dengan semangat kebersamaan supaya kelembagaan ekonomi yang dibentuk berjalan baik. Namun kenyataan dilapangan dalam pelaksanaanya partisipasi masyarakat masih minim. BUMDes sebagai institusi yang menaungi usaha milik desa berperan penting untuk meningkatkan sumber pendapatan desa dan juga sebagai penggerak sektor ekonomi masyarakat desa

Tidak dipungkiri bahwa BUMDes memiliki peran dalam perekonomian masyarakat, namun dalam pelaksanaan BUMDes masih mempunyai hambatan. Menurut penelitian yang telah dilakukan sebelumnya seperti penelitian dari kadek Rindi dkk, (2017) menyatakan bahwa kendala utama yang terjadi dalam pelaksanaan BUMDes adalah keterbatasan SDM yang ada. Dalam operasional BUMDes masih memiliki kendala yaitu kurangnya masyarakat yang ikut berpartisipasi dalam pengelolaan BUMDes karena dalam mengelola usaha desa ini masih mengandalkan sistem gotong royong sedangkan masyarakat memerlukan upah atas tenaganya. Dan juga anggaran dari dana desa juga masih sangat sedikit, sehinga rencana-rencana pengelola BUMDes dan pemerintah desa menjadi sulit teralisasikan. Secara konseptual keberhasilan BUMDes dilihat dari pengelolaannya, jika dilakukan dengan baik maka Pendapatan Asli Desa (PADes) dengan adanya peningkatan PADes, maka proses pembangunan dan kesejahteraan masyarakat dapat mengalami peningkatan. Namun untuk mewujudkannya diperlukan perhatian serta pemahaman tentang pengelolaan BUMDes yang ideal dan profesional.

Desa Bodas membentuk BUMDes sejak tahun 2016 dengan nama BUMDes Singajaya. Sudah hampir 4 tahun BUMDes Singajaya berjalan, namun dalam pengelolaannya belum dilakukan secara maksimal sehingga belum mampu mensejahterakan masyarakat secara luas masih dalam lingkup kecil. Dalam hal ini BUMDesSingajaya menjalankan usaha desa bergerak dalam penyewaan barang seperti sewa layos, mesin molen untuk aspal dan POM Bensin mini namun sedang tidak beroperasi. Pendapatan dari penyewaan barang tersebut masih kecil karena hanya bergantung pada tingkat acara yang ada. Selain itu, desa Bodas yang termasuk daerah gunung memiliki potensi alam seperti curug atau air terjun yang dapat dikembangkan menjadi wisata, namun berdasarkan penuturan ketua BUMDes Singajaya masih menjadi rencana karena melihat secara fisik sarana prasarana desa Bodas belum memadai. 
Sehingga diperlukan upaya untuk mengoptimalkan peran BUMDes Singajaya untuk meningkatkan pendapatan desa dan mensejahterakan warga desa dalam pengelolaanya.

Dengan adanya BUMDesSingajaya di desa Bodas diharapkan tidak hanya fokus pada hasil tetapi juga mendorong terbentuknya demokrasi sosial didesa dengan meningkatkan kapasitas masyarakat desa mengenai pelaksanaan BUMDes yang berkelanjutan, dan meningkatkan minat masyarakat desa dalam melaksanakan BUMDes Sinaga Jaya. Pemerintah desa melalui keberadaan BUMDes membutuhkan inovasi dan kreatifitas dalam sektor ekonomi desa, dengan begitu dapat memajukan perekonomian desa yang dibutuhkan serta terbuka lapangan kerja baru, menghasilkan kekhasan baik dari barang ataupun jasa daerah tersebut dan memberikan pelayanan umum yang optimal pada masyarakat. Berdasarkan uraian diatas maka tujuan peneliti dalam penelitian ini adalah untuk mengetahui apakah BUMDes Singajaya sudah berperan secara Optimal dalam mensejahterakan masyarakat desa Bodas atau belum.

\section{KAJIAN TEORI}

\section{Pengertian Desa}

Berdasarkan penelitian Irfan Nursetiawan (2018) menjelaskan "Desa merupakan suatu hasil perpaduan antara kegiatan sekelompok manusia dengan lingkungannya. Hasil perpaduan tersebut sebagai wujud atau ketampakan di muka bumi yang ditimbulkan oleh unsur-unsur fisiografis (fisis), sosial, ekonomi, politik, dan kultural yang saling berinteraksi di antara unsur tersebut, serta hubungannya dengan daerahdaerah lain”.

Undang-undang Nomor 6 Tahun 2014 mendefinisikan "Desa adalah kesatuan masyarakat hukum yang memiliki batas wilayah yang berwenang untuk mengatur dan mengurus urusan pemerintahan, kepentingan masyarakat setempat berdasarkan prakarsa masyarakat, hak asal usul atau tradisional yang diakui dan dihormati dalam sistem pemerintahan NKRI". Berdasarkan undang-undang diatas diketahui desa mempunyai wewenang untuk mengatur wilayah sendiri untuk mensejahterakan masyarakat.

\section{Badan Usaha Milik Desa (BUMDes)}

Pengertian BUMDes atau Badan Usaha Milik Desa menurut Permendesa PDTT No. 4 Tahun 2015 tentang pendirian, pengurusan, dan pembubaran Badan Usaha Milik 
Desa adalah "usaha yang seluruh atau sebagian besar modalnya dipisahkan guna mengelola aset, jasa pelayanan dan usaha lainnya untuk sebesar-besarnya kesejahteraan masyarakat desa".

Berdasarkan hasil penelitian yang dilakukan oleh Pradnyani (2019) menjelaskan pengertian BUMDes yaitu "suatu badan yang didirikan atau dibentuk secara bersama oleh masyarakat dan pemerintah desa da pengelolaannya dilakukan oleh pemerintah desa dan masyarakat dalam rangka memperoleh keuntungan bersama sebagai salah satu sumber Pendapatan Asli Desa”.

Menurut Peraturan Pemerintah Nomor 72 Tahun 2005 tentang Desa bahwa pemerintah desa dapat mendirikan Badan Usaha Milik Desa untuk peningkatan pendapatan desa dan masyarakat, yang disesuiakan dengan kebutuhan dan potensi desa yang ada. Dijelaskan juga dalam UU Nomor 32 Tahun 2004 tentang Pemerintahan Daerah desa dapat mendirikan badan usaha sesuai dengan potensi dan kebutuhan desa. Dengan begitu pembentukan BUMDes harus didasarkan pada potensi, kebutuhan serta kapasitas desa yang ada. Selain itu pendirian BUMDes dilakukan atas inisiatif masyarakat yang didukung pemerintah desa agar tercipta kemajuan ekonomi pada masyarakat desa.

\section{Kesejahteraan Masyarakat}

Menurut Sudarsono (1982: 32) kesejahteraan Masyarakat merupakan "Kondisi Ekonomi yang baik karena berlakuknya aturan dalam perekonomian yang mengatur aktifitas dari semua pihak dan pembagian pendapatan masyarakat sebagai hasil kegiatan ekonomi tersebut".

Kesejahteraan sosial telah dijelaskan dalam UU Nomor 11 Tahun 2009 tentang Kesejahteraan Sosial Pasal 1 Ayat 1 yaitu "kondisi terpenuhinya kebutuhan material, spiritual, dan sosial warga negara agar bisa hidup layak dan mampu mengembangkan diri sehingga dapat melaksanakan fungsi sosialnya. Upaya untuk mewujudkan suatu kesejahteraan sosial, meliputi rehabilitasi sosial, perlindungan sosial, pemberdayaan sosial, dan jaminan sosial".

Kesejahteraan dapat tercapai apabila dalam suatu tindakan mampu menumbuhkan rasa puas yang disesuaikan terhadap sumber daya yang dimiliki. Kesejahteraan masyarakat dapat digambarkan sebagai suatu kedaan yang tidak hanya mementingkan suatu aspek tertentu saja namun untuk banyak aspek. Faktor yang dapat mempengaruhi 
kesejahteraan masyarakat tidak hanya ekonomi saja tetapi juga non ekonomi yaitu seperti budaya, sosial, serta politik.

\section{METODE PENELITIAN}

Penelitian ini termasuk dalam jenis penelitian kualitatif. Karena penelitian ini menghasilkan data deskriptif berupa tulisan atau perkataan dari orang-orang atau pelaku yang diamati (Moleong, 2002:3). Teknik pengumpulan data yang dilakukan oleh peneliti yaitu dengan melalui wawancara tehadap narasumber terkait yaitu ketua, sekretaris, dan bendahara BUMDes Singajaya dan observasi langsung di desa Bodas. Lokasi penelitian adalah Desa Bodas kecamatan Watukumpul Kabupaten Pemalang Jawa Tengah alasan pemilihan tempat karena desa Bodas merupakan lingkungan peneliti tinggal dan juga manfaat BUMDes yang ada belum bisa secara maksimal menjangkau kesejahteraan masyarakat desa.

\section{HASIL DAN PEMBAHASAN}

\section{Keberadaan Badan Usaha Milik Desa (BUMDes) Di Desa Bodas}

Pembentukan BUMDes Singajaya desa Bodas telah diatur dalam peraturan desa Bodas pada tahun 2016 tentang pembentukan badan usaha milik desa (BUMDes) Singajaya desa Bodas kecamatan Watukumpul kabupaten Pemalang sesuai dengan amanat Undang-undang Nomor 6 Tahun 2014 tentang desa pada Pasal 87 diatur bahwa “(1) desa dapat mendirikan Badan Usaha Milik Desa yang disebut BUMDes, (2) BUMDes dikelola dengan semangat kekeluargaan dan kegotongroyongan, (3) BUMDes dapat menjalankan usaha di bidang ekonomi dan/atau pelayanan umum sesuai dengan ketentuan peraturan perundang-undangan”. Dan juga berpedoman pada peraturan bupati Pemalang nomor 68 tahun 2007 tentang petunjuk pelaksanaan peraturan daerah kabupaten pemalang Nomor 9 tahun 2007 tentang Pedoman Pemebentukan Badan Usaha Milik Desa.

Kegiatan BUMDes Singajaya dalam proses operasionalnya masih menggunakan transaksi yang sederhana sehingga pengelola belum menyediakan tempat khusus untuk menjalankan usaha sampai saat ini kegiatan usaha tersebut dilakukan di kantor balai desa Bodas. Pengurus BUMDes Singajaya sudah menyusun struktur organisasi dan juga AD/ART dengan baik sesuai kesepakatan bersama dalam rapat rutin yang dilakukan oleh 
perangkat Desa serta Pengurus yang ditunjuk. AD/ART tersebut disepakati digunakan untuk panduan kegiatan selama tiga tahun. Untuk perubahan dalam AD/ART telah disepakati dapat diadakan berdasarkan pada hasil evaluasi terinci dari laporan oleh pengurus BUMDes dan atau perangkat desa. Berdasarkan peraturan desa Bodas tahun 2016 pasal 7 tentang pembentukan badan usaha milik desa (BUMDes) Singajaya bertujuan untuk: 1) Menunjang pembangunan desa; 2) Ikut serta dalam pembangunan ekonomi desa; dan 3) Memberi pelayanan kepada masyarakat secara adil dan merata.

Keberadaan Badan Usaha Milik Desa (BUMDes) Singajaya sebagai wujud untuk memaksimalkan pengelolaan ekonomi produktif desa yang selama ini dilakukan oleh pemerintah desa. Dalam upaya pemenuhan kebutuhan (produktif dan konsumtif) masyarakat desa Bodas. BUMDesSingajaya bergerak dalam bisnis penyewaan barang seperti sewa layos dan panggung, sewa mesin molen untuk aspal jalan dan juga usaha perdagangan yaitu POM Bensin Mini, namun untuk sementara ini POM mini tidak berfungsi karena ada kerusakan dan belum diperbaiki terkendala oleh belum menemukan orang yang ahli dibidangnya serta tidak ada keluangan waktu dari orang tersebut untuk memperbaikinya. Perkembangan usaha desa ini menurut ketua BUMDe sejak awal berdiri pada tahun 2016 hingga saat ini sedikit demi sedikit sudah mengalami peningkatan. Terdapat juga rencana usaha lain dari BUMDes yaitu menambah kursi dan meja yang nantinya satu paket dengan layos dan panggung, namun rencana ini belum terwujud karena terkendala modal dan sumber daya manusia yang dirasa masih belum mampu mengelola BUMDes. Sehingga dalam pengelolaanya pemerintah desa Bodas harus memberikan perhatian besar terhadap usaha milik desa ini melihat manfaat keberadaannya BUMDesSingajaya belum dapat dirasakan secara langsung oleh masyarakat.

Penyertaan Modal awal oleh Pemerintah Desa Bodas ke BUMDesa Singajaya bersandar pada pasal 135 UU. No 6 tahun 2014. Modal awal BUMDES bersumber dari dana APB Desa melalui musyawarah dengan masyarakat.Menurut Muhammad Fajar dan Rahayu (2019) beberapa modal BUMDES terdiri atas Penyertaan modal dari desa dan masyarakat desa. Penyertaan modal desa sebagaimana dimaksud berasal dari APB Desa dan sumber lainnya yaitu dapat bersumber dari : 1. Dana segar, 2. Bantuan yang diberikan pemerintah, 3. Bantuan dari pemerintah daerah dan, 4. Aset desa yang diserahkan kepada APB Desa. Penyaluran bantuan pemerintah tersebut dimasukkan dalam APB Desa yang 
akan diberikan kepada BUMDES. Pemerintah Desa Bodas memberikan modal awal ke BUMDesa Singajaya sudah dilakukan sejak awal didirikan yaitu meliputi Bantuan Pronvinsi Jawa Tengah Rp 30.000.000 pada triwulan ke empat tahun 2017 dan mendapat Penyertaan Modal dari Dana Desa Rp 10.000.000 untuk pembelian Molen dan pada tahun 2018 mendapat penyertaan Modal dari Dana Desa Rp 50.000.000 untuk pembelian Pertamini. Namun berdasarkan penuturan bendahara BUMDes modal usaha yang dimiliki BUMDes Singajaya desa Bodas masih tergolong minim bahkan untuk dua tahun ini yaitu tahun 2019 dan tahun 2020 BUMDes tidak mendapatkan modal usaha karena permodalan usaha BUMDes masih hanya mengandalkan dana desa sedangkan dana desa oleh pemerintah desa difokuskan untuk pembangunan fisik desa karena untuk infrastruktunya masih memelukan perbaikan. Dan untuk tahun 2020 dengan adanya pandemi Covid-19 berdampak pada ekonomi masyarakat desa sehingga dana desa diberikan kepada masyarakat desa untuk membantu perekonomiannya. Hal ini mengakibatkan produk rencana desa semakin sulit untuk direalisasikan sekaligus meningkatkan apatisme masyarakat.

Keberadaan BUMDes Singajaya di desa Bodas sudah banyak diketahui masyarakat desa, namun dalam pelaksanaanya minat masyarakat untuk mengelola BUMDes masih sangat sedikit karena kurangnya kesadaran masyarakat mengenai kegiatan usaha milik desa. Selain itu, pemerintah desa Bodas masih mementingkan pembangunan infrastruktur desa dan kurang memeperhatikan pembangunan ekonomi masyarakat desa. sehingga peran pemerintah desa sangat diperlukan untuk memberikan pemahaman kepada masyarakatnya agar terciptalah kemandirian ekonomi desa.

\section{Peran BUMDesSingajaya dalam perekonomian masyarakat desa Bodas kecamatan Watukumpul kabupaten Pemalang}

Sesuai dengan tujuan didirikannya BUMDes, maka dari wawancara kepada ketua pengelola usaha desa menyatakan bahwa BUMDes Singajaya sudah mejalankan peran sebagai penyedia pelayanan umum bagi masyarakat dan pengembangan potensi masyarakat sehingga mampu tercipta suasana kemungkinan adanya potensi masyarakat dapat berkembang. BUMDes Singajaya telah berkontribusi memberikan peranan dalam 
mensejahtrakan masyarakat desa Bodas melalui peranan ekonomi yaitu bisnis penyewaan barang (seperti layos, mesin molen untuk aspal). BUMDes menyewakan barang kepada masyarakat dengan tarif sewa yang lebih murah dibandingkan dengan menyewa dari luar. Biaya sewa tersebut disesuaikan dengan jarak penyewa seperti pada layos dan panggung tarif penyewaannya sebesar Rp.500.000 untuk lingkup desa Bodas sedangkan jika memakai penyewa dari luara biaya sewa bisa lebih mahal. sehingga dapat membantu meringankan beban ongkos sewa masyarakat desa yang akan menggunakan barang tersebut baik untuk hajatan maupun untuk acara lainnya. Selanjutnya untuk mesin molen yang digunakan untuk mengaspal jalan biaya sewanya lebih murah dibandingkan menyewa mesin dari luar. Dengan begitu pengeluaran dana desa menjadi lebih hemat sehingga dana dapat digunakan untuk banyak hal.

BUMDes Singajaya juga memiliki peranan dalam menciptakan lapangan kerja baru bagi masyarakat desa meski dalam skala kecil karena bisnis penyewaan barang ini hanya mengandalkan acara yang ada. Untuk memenuhi kebutuhan masyarakat dalam penyewaan barang diperlukan tenaga kerja dari masyarakat untuk mengerjakannya, contoh untuk penyewaan layos memerlukan kurang lebih 5 orang dalam pemasangannya. Dengan begitu dapat mengurangi pengangguran masyarakat karena mereka memperoleh pekerjaan dan juga upah atau penghasilan atas kerjanya.

Hal ini sama dengan hasil penelitian yang dilakukan pradnyani (2019) yaitu BUMDes dapat membuka lapangan pekerjaan bagi masyarakat desa Tibubeneng sehingga dapat mengurangi pengangguran. Penelitian Darwita dan Redana (2018) mengatakan peran BUMDes Teja Kusuma dalam penanggulangan pengangguran sudah dapat dikatakan terlaksana, walaupun masih dalam sekala kecil.

Selanjutnya BUMDes Singajaya tidak hanya berperan terhadap masyarakat tetapi juga dalam peningkatan Pendapatan Asli Desa (PADes). Dari penuturan bendahara BUMDes hasil usaha penyewaan barang yang didapat setelah dikurangi biaya tenaga kerja transportasi dan juga sewa gedung kelebihannya dimasukkan untuk kas BUMDes sebagai saldo dan menjadi Pendapatan Asli Desa. Namun karena bisnis penyewaan barang ini hanya mengandalkan acara yang ada, maka pendapatan asli desa masih kecil karena keuntungan yang diperoleh masih sedikit. Sehingga diperlukan tata pengelolaan yang baik supaya keberadaan BUMDes Singajaya dapat mengalami peningkatan yang optimal. 
Berdasarkan penjelasan diatas BUMDes Singajaya dalam kesejahteraan masyarakat sudah berperan baik, namun dalam pelaksanaannya belum berjalan maksimal masih diperlukan inovasi dalam kegiatan usahanya supaya menarik masyarakat untuk ikut berpartisipasi dalam menjalankan usaha desa ini. Manfaat keberadaan BUMDes Singajaya ini belum dirasakan masyarakat luas secara langsung hanya beberapa masyarakat saja. Dan juga dalam penyerapan tenaga kerja dan pendapatan asli desa masih belum dilakukan dengan maksimal. Menurut Solekhan (2014: 73) agar usaha milik desa berjalan dengan baik memerlukan konsep pengelolaan yang baik antara lain yaitu : 1) Harus dilakukan secara transparansi atau terbuka dalam pengelolaannya supaya dapat diketahui oleh masyarakat. 2) Harus ada pertanggung jawaban pengelolaan BUMDes kepada masyarakat desa sesuai dengan peraturan dan kaidah yang berlaku. 3) Pentingnya keaktifan partispiasi dari masyarakat baik dalam perencanaan, pelaksanaan dan ikut serta dalam pengawasan. 4) Dalam pengelolaan BUMDes harus dapat menghasilkan manfaat bagi masyarakat.

\section{Kendala BUMDesSingajayadalam Meningkatkan Kesejahteraan Desa Bodas}

Implementasi peran BUMDes Singajaya dalam meningkatkan kesejahteraan masyarakat desa Bodas dalam pengelolaanya mempunyai kendala yang dihadapi. Kendala tersebut disebabkan beberapa hal antara lain pertama sumber daya manusia yang ada masih terbatas. Hal ini dapat dilihat masih minimnya partisipasi masyarakat dalam mengelola BUMDes Singajaya bahkan dalam mengelola usaha desa ini belum terdapat karyawan yang tetap. Sumber daya manusia menjadi faktor yang tidak dapat dipisahkan dan sangat penting dalam organisasi pemerintahan desa. Menurut ketua BUMDes Dalam pelaksanaan usaha masih sulit untuk mencari masyarakat yang berminat mengelola usaha desa dan masih rendahnya tenaga ahli dalam berwirausaha. Sehingga kinerja BUMDes belum efektif dalam pengelolaan usahanya.

Permasalahan kedua yaitu kapasitas manajerial di desa Bodas masih rendah dalam pengelolaan BUMDes desa Bodas terutama mengenai hal keuangan. Dalam pencatatatan laporan keuangan pengelola BUMDes Singajaya masih dilakukan secara sederhana belum sesuai dengan Standar Akuntansi keuangan Etentitas Tanpa Akuntabilitas Publik (SAK-ETAP). Karena pengelola belum mendapat pendampingan mengenai penyusunan laporan keuangan yang sesuai standar akuntansi secara umum. Laporan keuangan berperan penting dalam pengelolaan karena dapat digunakan sebagai tolak ukur peran 
BUMDes dalam meningkatkan pendapatan desa dan juga sebagai evaluasi kinerja BUMDes yang dilakukan. Pengelola dalam pelakasanaan usaha desa ini memerlukan peningkatan kapasitas manajerial yang profesionali serta inovatif agar usaha desa dapat berkembang dengan baik.

Kendala ketiga adalah keterbatasan pemodalan menurut ketua pengelola mengatakan bahwa dalam mengembangkan usaha diperlukan modal yang tidak sedikit, diketahui modal awal BUMDes Singajaya sebesar Rp. 40.000.000 telah dibelanjakkan untuk pembelian layos dan panggung. Kemudian untuk dua tahun terakhir BUMDes belum mendapatkan modal dari dana desa karena pemerintah masih memprioritaskan pembangunan fisik desa. Desa Bodas memiliki potensi alam yang besar yaitu terdapat air terjun dan hutan masih asri yang dapat dikembangkan untuk wisata namun karena modal yang dimiliki BUMDes masih minim potensi tersebut belum dimanfaatkan. Hal ini karena modal untuk pengelolaan hanya mengandalkan dana desa saja. Peran pemerintah desa untuk melakukan pelatihan pada masyarakat diperlukan guna menggalih kreatifitas masyarakat agar dapat mendorong perkembangan usaha BUMDes Singajaya dalam pengelolaannya dan dapat meningkatkan keuntungan usaha maka PADes juga akan meningkat dengan begitu tercipta kemandirian ekonomi sehingga modal tidak lagi hanya bergantung pada dana desa. Tidak hanya itu, dengan peningkatan keuntungan usaha tersebut dapat digunakan untuk merealisasikan rencana pengembangan potensi alam lainnya yang ada di desa Bodas.

\section{Optimalisasi Peran BUMDes Singajaya dalam Mensejahterakan Masyarakat Desa} Bodas

BUMDes Singajaya dalam mensejahterakan masyarakat sudah berperan dengan cukup baik, namun pengelolaannya belum dilakukan secara optimal dilihat dari perkembangan usaha BUMDes Singajaya yang masih lambat. Sehingga untuk mengoptimalkan peran BUMDes Singajaya di desa Bodas memerlukan beberapa upaya agar manfaat keberadaan usaha milik desa ini dapat dirasakan merata oleh masyarakat desa. Upaya yang dapat dilakukan oleh pemerintah desa yaitu untuk memberikan sosialisasi tentang pengelolaan BUMDes terhadap masyarakat desa Bodas guna meningkatkan minat serta pengetahuan masyarakat dalam mengelola usaha milik desa ini. Dengan semakin banyak masyarakat yang memiliki keinginan memajukan 
perekonomian ikut serta dalam mengelola BUMDes hal ini dapat memaksimalkan pelaksanaan BUMDes.

Selanjutnya adalah diadakan Pendampingan dan pelatihan terhadap pengelola serta masyarakat desa juga untuk meningkatkan kapasitas manajerial dan terutama Sumber Daya Manusia yang masih rendah mengenai perencanaan, pelaksanaan dan pengelolaan BUMDes Singajaya agar usaha milik desa dapat dijalankan secara maksimal dan juga demi keberlanjutan usaha desa. Selain itu juga untuk menggali potensi alam desa Bodas yang belum dikembangkan dan dimanfaatkan untuk kesejahteraan masyarakat desa. Sehingga dengan pelatihan dan pendampingan tersebut diharapkan mampu membangun kreatifitas, inovasi serta profesionalitas dalam pengelolaan BUMDes Singajaya. Karena dengan tata kelola yang baik dalam organisasi dapat mengoptimalkan peranan BUMDes Singajaya untuk meningkatkan kesejahteraan masyarakat serta perekonomian desa.

Sejalan dengan penelitian yang telah dilakukan oleh Siga (2019) pengelolaan BUMDes harus mampu meningkatkan kualitas pelayanan dan meningkatkan tata kelola organisasi sehingga dapat meningkatkan perekonomian dan kesejahteraan desa, tercipta peluang pekerjaan dan membuka jaringan pasar yang mendukung pemenuhan kebutuhan layanan umum warga, meningkatkan pertumbuhan dan pemerataan ekonomi desa, dan meningkatkan pendapatan masyarakat desa dan pendapatan asli desa. Penelitian Anggraini (2016) bahwa profesionalisme menjadi tuntutan bagi pengelola BUMDes dalam peningkatan pelayanan serta kemampuan dalam mengelola organisasi. Dan penelitian Ridlwan (2014) menyimpulkan kegiatan BUMDes yang dilakukan secara prosional dan juga ideal dapat meningkatkan ekonomi baik secara lokal dan regional dalam perekonomian nasional.

\section{KESIMPULAN}

Keberadaan Badan Usaha Milik Desa (BUMDes) di Desa Bodas mengacu pada Peraturan Pemerintah Daerah Pemalang No. 9 Tahun 2007 tentang Pedoman Pembentukan Badan Usaha Milik Desa. Pembentukan badan usaha milik desa. Pembentukan BUMDes Singajaya di desa Bodas sudah banyak diketahui masyarakat desa, namun dalam pelaksanaanya minat masyarakat masih terbatas. Pelaksanaan Badan Usaha Milik Desa (BUMDes) Singajaya sebagai wujud untuk memaksimalkan 
pengelolaan ekonomi produktif desa.Peran BUMDesSingajaya dalam perekonomian masyarakat desa Bodas sudah berperan cukup baik dalam mensejahterakan perekonomian masyarakat desa, membuka lapangan pekerjaan baru untuk mengurangi pengangguran walau dalam skala kecil serta peningkatan dalam Pendapatan Asli Desa yaitu melalui usaha penyewaan barang (seperti layos, mesin molen untuk aspal) dengan tarif yang lebih kecil walau dalam pengeolannya belum berjalan dengan maksimal.Adapunbeberapakendalayang dihadapi olehBUMDes Singajaya adalah pertama, sumber daya manusia yang ada masih terbatas. Kedua, masih rendahnya kapasitas manajerial dalam pengelolaan BUMDes Singajaya desa Bodas terutama mengenai hal keuangan. Ketiga, masih minimnya permodalam dalam mengelola BUMDes Singajaya, sehingga masih ada potensi desa yang ada belum dimanfaatkan. Oleh karena itu,untuk mengoptimalkanperan BUMDes Singajaya dalam mensejahterakan masyarakat desa Bodas maka perlu dilakukan beberapa kegiatan, yaitu dengan mengadakan sosialisasi serta pelatihan dan penadampingan kepada masyarakat untuk meningkatkan kreatifitas, inovasi serta profesionalitas dalam pengelolaan BUMDes Singajaya dan juga untuk menggali potensi desa yang ada.

\section{DAFTAR PUSTAKA}

Angraeni. M. R. R. S. (2016). Peranan Badan Usaha Milik Desa (BUMDes) Pada Kesejahteraan Masyarakat Pedesaan Studi Pada BUMDes Di Gunung Kidul, Yogyakarta. MODUS. 28 (2). 155-167.

BUMDes. http//:BUMDes.id/2020/01/diskusi-resolusi-budes. Diakses pada 10 Desember2020.

Caya, M. F. N., \& Rahayu, E. (2019). Dampak BUMDes Terhadap Kesejahteraan Masyarakat Di Desa Aik Batu Buding, Kabupaten Belitung, Provinsi Bangka Belitung. Journal Of Social Welfare, 20(1). 1-12.

Darwita, I. K., \&Redana, D. N. (2018). PerananBadan Usaha MilikDesa (BUMDes)

DalamPemberdayaanMasyarakat Dan PenanggulanganPengangguran Di DesaTejakulaKecamatanTejakulaKabupatenBuleleng. Locus. 9.(1).

Lexy. J. Moleong. (2002). Metode Penelitian Kualitatif.Bandung: Remaja Rosdakarya. Nursetiawan, I. (2018). Strategi Pengembangan Desa Mandiri Melalui Inovasi BUMDES. Moderat: Jurnal Ilmiah Ilmu Pemerintahan. 4(2). 72-81. 
Peraturan Menteri Dalam Negeri Nomor 39 Tahun 2010 tentang Badan Usaha Milik Desa.

Peraturan Menteri Desa PDTT No. 4 Tahun 2015 tentang Pendirian, Pengurusan, dan Pembubaran Badan Usaha Milik Desa.

Peraturan Daerah Kabupaten Pemalang No. 9 Tahun 2007 tentang Pedomn Pembentukan Badan Usaha Milik Desa.

Peraturan Pemerintah Nomor 72 Tahun 2005 tentang Desa.

Pradnyani, N. L. P.S. P. (2019). Peranan Badan Usaha Milik Desa (BUMDes) Dalam Meningkatkan Kesejahteraan Masyarakat Di Desa Tibubeneng Kuta Utara. Jurnal Riset Akuntansi (JUARA). 9 (2). 39-47.

Ridlwan Zulkarnain. (2017). Urgensi Badan Usaha Milik Desa (BUMDes) Dalam Pembangunan Perekonomian Desa. Fiat Justisia Jurnal Ilmu Hukum. 8 (3). 424440.

Rindi, K., Dewi, L. P. M. S. A., Sari, D. A. P., \& Awitiana, P. P. (2019). Penerapan Prinsip Akuntabilitas Pada BUMDes Teja Kusuma. Jurnal Ilmiah Akuntansi Dan Humanika. 7(1).

Siga, W. D. (2020). Peranan Badan Usaha Milik Desa Terhadap Pengelolaan Potensi Desa Bagi Kesejahteraan Masyarakat Kajian Pada BUMDes Malar Walatra, Desa Subang, Kecamatan Subang, Kabupaten Kuningan, Jawa Barat. Inovasi. 7(1). 3241.

Sudarsono. 1982. Pengantar Ekonomi Mikro.Jakarta: LP3ES.

Undang-Undang Republik Indonesia Nomor 32 Tahun 2004 tentang Pemerintahan Daerah.

Undang-Undang Republik Indonesia Nomor 6 Tahun 2 